\title{
Development and Research
}

\section{of the Innovative Production Technology \\ of Multifunctional Invar Alloys New Generation}

\author{
Mikhail V. Chukin, Eduard M. Golubchik, \\ Natalia V. Koptseva, Yulia Yu. Efimova, \\ Dmitry M. Chukin and Ekaterina M. Medvedeva* \\ Nosov Magnitogorsk State Technical University \\ 38 Lenin, Magnitogorsk, 455000, Russia
}

Received 07.02.2016, received in revised form 11.03.2016, accepted 27.05.2016

Recently materials on the basis of multipurpose alloys with special mechanical and physical properties are widely adopted for creation of equipment of new generation. Such materials include Invar alloys with a minimum value of thermal expansion with high strength characteristics and hardness. Results of complex researches on influence of the modes of heat treatment on formation of structure are presented in article on the example of an alloy 32NUFM.

Keywords: multifunctional alloy, high-strength invar, heat treatment, hardness, microstructure.

Citation: Chukin M.V., Golubchik E.M., Koptseva N.V., Efimova Y.Yu., Chukin D.M., Medvedeva E.M. Development and research of the innovative production technology of multifunctional invar alloys new generation, J. Sib. Fed. Univ. Eng. technol., 2016, 9(5), 744-749. DOI: 10.17516/1999-494X-2016-9-5-744-749.

(c) Siberian Federal University. All rights reserved

* Corresponding author E-mail address: fekla_med@mail.ru 


\title{
Разработка и исследование
}

\section{инновационной технологии}

изготовления многофункциональных

инварных сплавов нового поколения

\author{
М.В. Чукин, Э.М. Голубчик, Н.В. Копцева, \\ Ю.Ю. Ефимова, Д. М. Чукин, Е.М. Медведева \\ Магнитогорский государственный \\ технический университет им. Г.И. Носова \\ Россия, 455000, Магнитогорск, ул. Ленина, 38
}

$B$ последнее время для создания техники нового поколения широкое распространение получают материаль на базе многофункциональных сплавов с особыми физикомеханическими свойствами. К таким материалам можно отнести инварные сплавь, обладаюшие минимальным значением теплового расширения с высокими прочностными характеристиками. В статье на примере сплава 32 НУФМ представлень результаты комплексных исследований по влиянию режимов термической обработки на формирование структуры.

Ключевые слова: многофункииональные сплавы, высокопрочные инвары, термообработка, твердость, микроструктура.

Recently materials on the basis of multipurpose alloys with special physical and mechanical characteristics are widely adopted for creation of equipment of new generation. Such materials are invar alloys which have the minimum value of the temperature coefficient of linear expansion (TCLE) in combination with high strength characteristics. Scientists of Nosov Magnitogorsk State Technical University in cooperation with leading experts of PJSC Motovilikhinskie Zavodi (Perm) developed principally new high-strength multipurpose alloys of an invar class on basis of Fe-Ni-C. The developed materials possess low values of TCLE $\left(<2 \cdot 10^{-6} \mathrm{~K}^{-1}\right)$ and at the same time increased level of strength properties $\left(\sigma_{\mathrm{B}} \approx 800 \div 1300 \mathrm{M \Pi а}\right)[1-4]$.

The manufacturing technique of new high-strength multipurpose alloys of invar type is developed and adapted for conditions of industrial production and involves the following (without details): smelting of alloys in the vacuum induction furnace, forging on the intermediate size, hot high-quality rolling, finishing multiple-stage heat treatment (quenching, annealing, the lowtemperature stabilization).

Electronic and microscopic researches and the X-ray diffraction analysis were carried out in Nosov Magnitogorsk State Technical University on the experimental lengthy pieces made together with PJSC Motovilikhinskie Zavodi for identification of influence of the heat treatment conditions on formation of structure and properties of pieces from multipurpose invar alloys of new generation. Experiments were carried out on pieces from an invar type alloy with a chemical composition: $\mathrm{Fe}-$ $34,7 \mathrm{Ni}-0,4 \mathrm{C}-1,0 \mathrm{~V}-2,3 \mathrm{Mo}$, that approximately corresponds to grade alloy 34NUFM.

Microslices of samples were made by a standard technique for the metallographic analysis. The surface of metallographic section was exposed to etching in nital (4\%) by immersion technique of the 
polished surface in a bath for identification of a microstructure. Microslices surfaces were investigated using an optical microscope at magnification of 50-1000 power with usage of the computer analysis system of images Thixomet PRO for detection of qualitative and quantitative structural features. The microstructure at magnification more than $1000 \mathrm{X}$ was investigated by the raster electronic microscopy (REM) in secondary and low-loss electrons by the scanning electronic microscope.

Microstructure of an alloy is presented in Fig. 1. It is an initial state before the heat treatment. Numerous nonmetallic inclusions were found on not etched metallographic section (Fig. 1a). Results of light microscopy of etched metallographic section showed that the alloy microstructure is the heterogeneous system consisting of grains of various size and particles of the second phase of various dispersion (Fig. 1b).

X-ray microanalysis was carried out for identification of the chemical elements which are a part of structural components of an alloy. Results are illustrated on the Fig. 2 and it shows that in the ranges received from a metal basis (matrix) of structure of an alloy 34NUFM peaks of $\mathrm{Fe}, \mathrm{Ni}$, and $\mathrm{C}$, and also

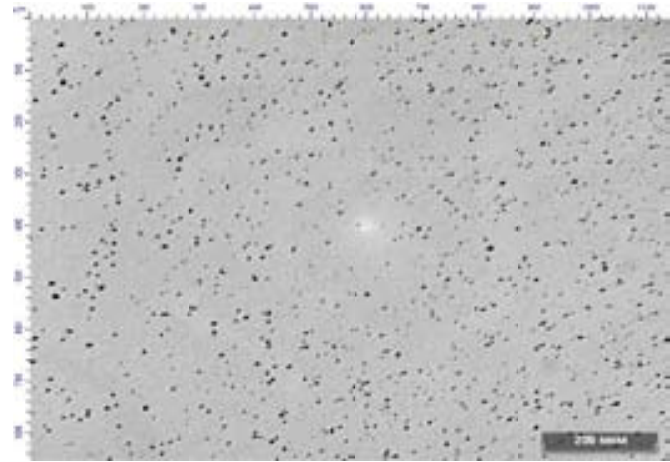

a

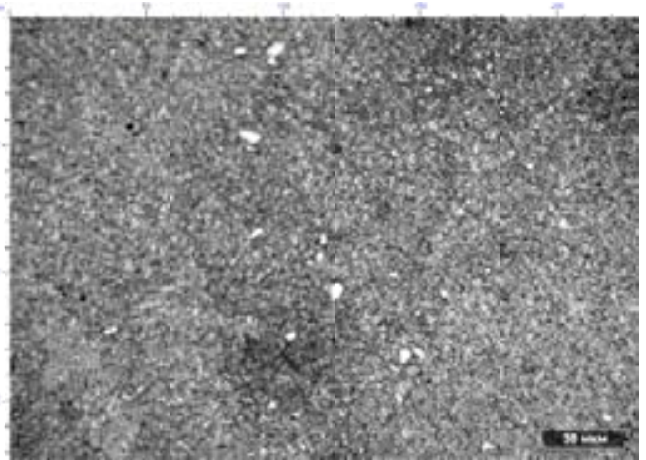

$\mathrm{b}$

Fig. 1. Nonmetallic inclusions (a) and alloy microstructure (b) in an initial condition of an alloy 34NUFM: a - x $100 ; b-x 500$

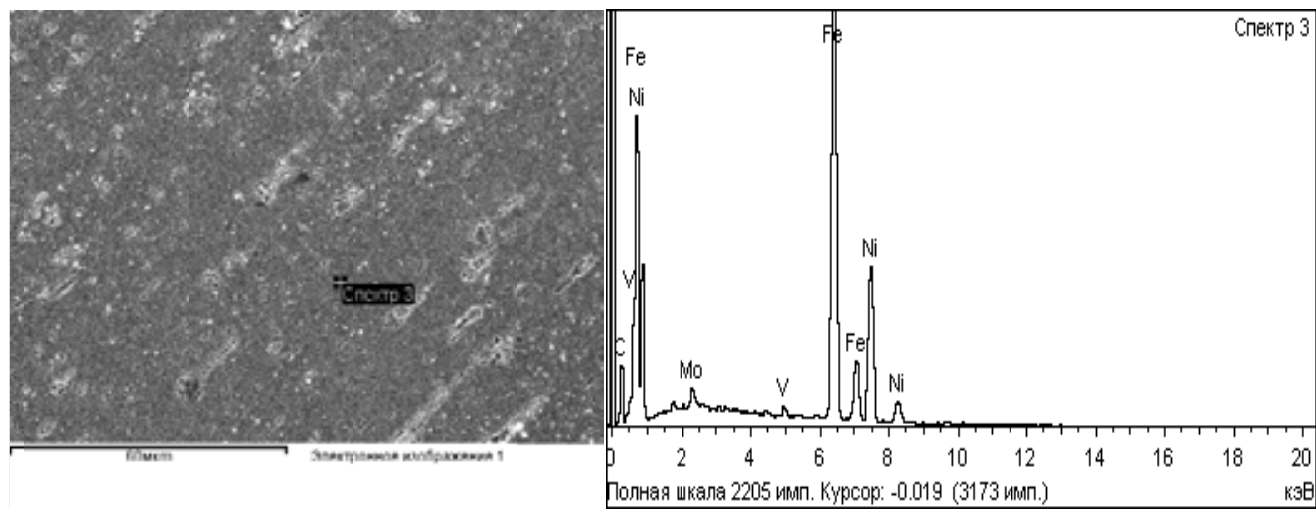

a

b

Fig. 2. The electronic image of an alloy microstructure of 34NUFM (a) in an initial state and the characteristic range removed from a matrix (b) 
Mo and $\mathrm{V}$ are found. It allows to identify an alloy matrix as the solid solution containing the specified elements.

Alloy 34NUFM was incurred to training from temperatures of 1200 and $1250{ }^{\circ} \mathrm{C}$ in water and oil. Distinctions in a microstructure of the tempered alloys were found. In case of training carried out from temperature of $1200^{\circ} \mathrm{C}$ the structure is more uniform and the grain size is up to 30 microns (Fig. $3 a$ ) (during water cooling) and up to 40 microns (Fig. $3 b$ during oil cooling) that corresponds to grain No. 6-7. When training is carried out from temperature of $1250^{\circ} \mathrm{C}$ the structure is non-uniform, distinction by the grain size is from 50 to 450 microns (Fig. 3c) (during water cooling) and from 40 to 450 microns (Fig. $3 d$ during oil cooling) that corresponds to grain from No. 6 to No. 1 . The reason of such distinctions is growth of grain at increasing of heating temperature during training. Thus owing to fuller dissolution of carbide particles (which, as we know, curb grains growth) in separate microvolumes of structure more intensive growth of grain is observed. When training is carried out from $1200{ }^{\circ} \mathrm{C}$ carbides are dissolved to a lesser extent and they curb grains growth during heating before training, resulting in the grain is small. Samples of the studied alloy 34NUFM after training from temperatures of 1200 and $1250^{\circ} \mathrm{C}$ in water and in oil were heated at temperatures: $300,500,600$, 650,700 , and $800{ }^{\circ} \mathrm{C}$, duration was 1 hour to provide disintegration of oversaturated $\gamma$-solid solution and to increase of strength characteristics.

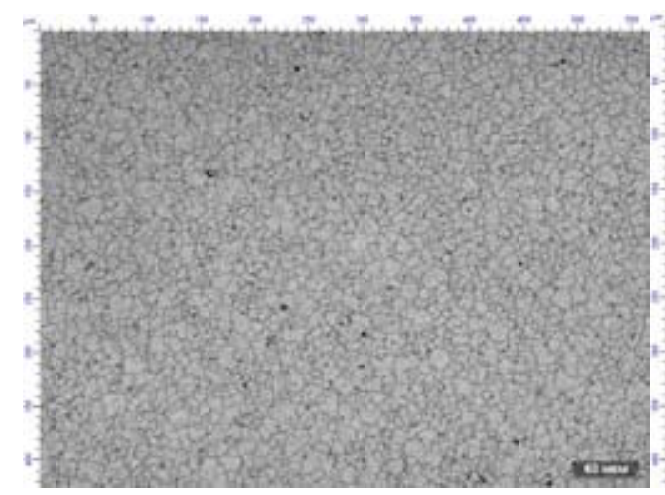

a

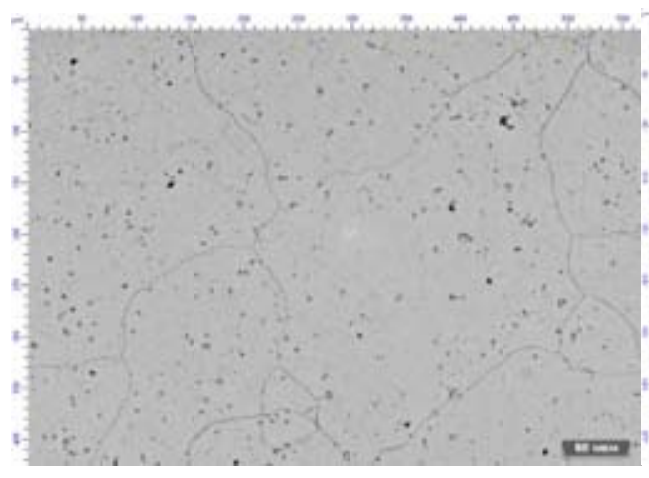

$\mathrm{c}$

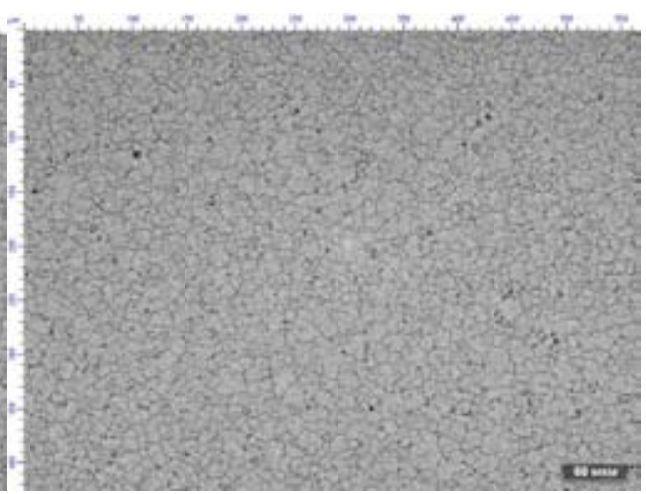

$\mathrm{b}$

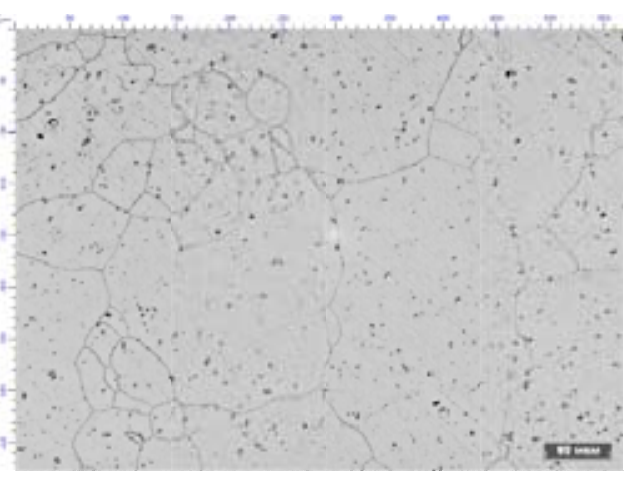

d

Fig. 3. A general view of a microstructure of an alloy 34NUFM after training from $1200{ }^{\circ} \mathrm{C}(\mathrm{a}, \mathrm{b})$ and $1250^{\circ} \mathrm{C}(\mathrm{c}$, d) in water (a, c) and oil (b, d), x 200 
The maximum of hardness is reached in the alloy tempered from temperature of $1200{ }^{\circ} \mathrm{C}$ in oil when heating were carried out in the range of temperatures of $600-700{ }^{\circ} \mathrm{C}$. When training was carried out from the same temperature in water the maximum is reached when heating was up to $700{ }^{\circ} \mathrm{C}$. Thus the maximum values of hardness are almost identical and these are 210-220 HV (2100$2200 \mathrm{MPa}$ ) (Fig. 4a).

When training is carried out from $1250{ }^{\circ} \mathrm{C}$ both in water and in oil hardness starts increasing already when heating temperature is $300{ }^{\circ} \mathrm{C}$, and it increases most intensively when heating in the range of temperatures of $500-700{ }^{\circ} \mathrm{C}$. Hardness reaches the maximum values when heating $700{ }^{\circ} \mathrm{C}$ and after training both in water and in oil. It should be noted that hardness of the alloy tempered in water after heating up to $700{ }^{\circ} \mathrm{C}$ is about $300 \mathrm{HV}(\sim 3000 \mathrm{MPa})$, and hardness of the alloy tempered in oil is only about $280 \mathrm{HV}(\sim 2800 \mathrm{MPa})$ (Fig. $4 b)$.

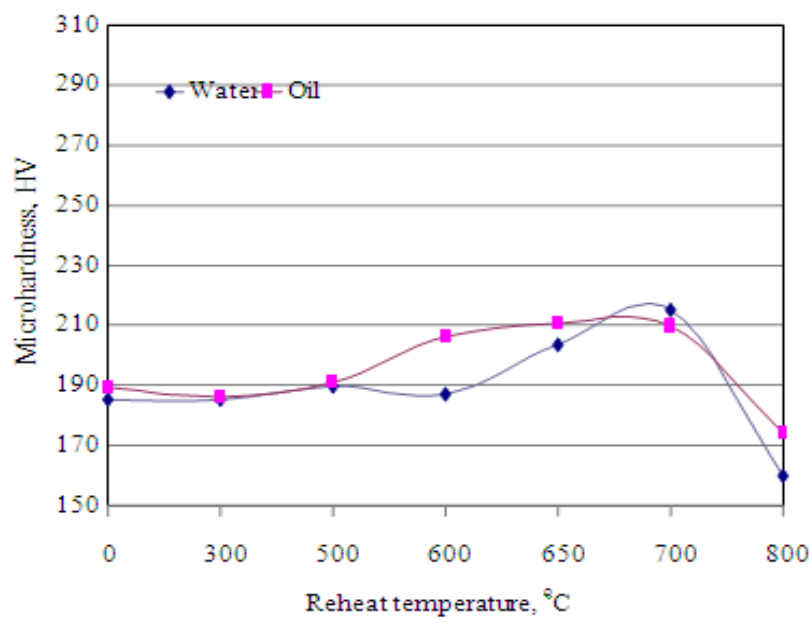

a

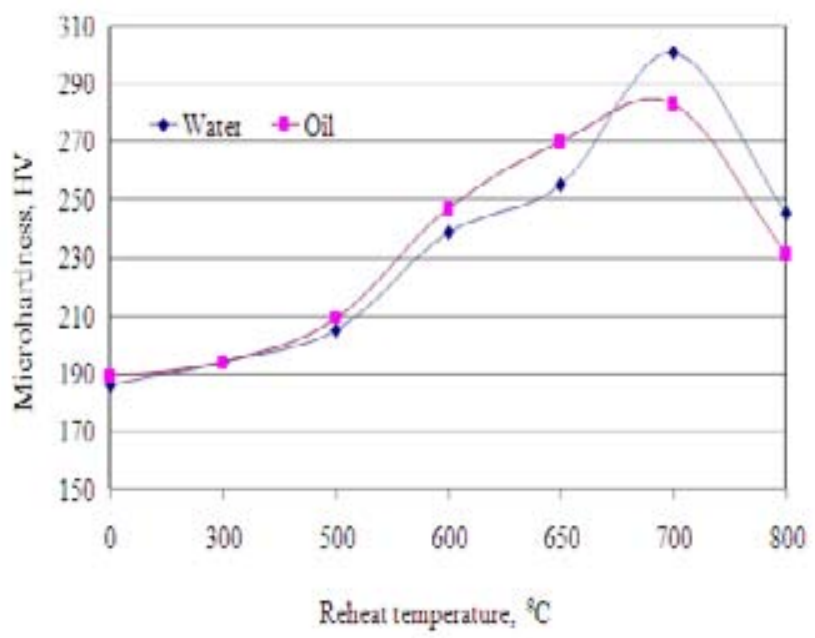

Fig. 4. Change of microhardness of the tempered alloy 34NUFM from temperature of the subsequent heating 


\section{Conclusions}

1. The researches results showed that in case of heating an invar alloy of type 34NUFM before training the dissolution of part of carbide phases inclusions is provided and the solid solution is saturated with carbon and alloying elements. When heating temperature before training increases up to $1250^{\circ} \mathrm{C}$, the fuller dissolution of carbides happens. During the training in oil the part of the dissolved carbides is precipitated, as a result the samples tempered in oil have higher hardness than alloys cooled in water.

2. During the increasing of the tempered alloys heating temperature the hardness at first increases, reaching a maximum that is connected with the strengthening particles precipitation. After achieved of the maximum value, hardness starts decreasing that can occur owing to the coagulation of precipitated particles. The maximum content of the strengthening phase in the tempered samples is observed after heating at $600-650{ }^{\circ} \mathrm{C}$. The X-ray microanalysis showed that the precipitated strengthening phase includes the difficult carbides containing carbide-forming element: molybdenum and vanadium, and also may contains the titan used as a part of the deoxidating mixes during smelting an alloy of the specified structure.

\section{References}

[1] Чукин М.В., Голубчик Э.М., Кузнецова А.С. и др. Разработка композиций многофункциональных сплавов инварного класса с расширенными эксплуатационными характеристиками. Вестник Магнитогорского государственного технического университета им. Г.И. Носова, 2013, 3, 62-66 [Chukin M.V., Golubchik E.M., Kuznetsova A.S. et al. Development of multifunctional compositions of alloys invar class with advanced performance. Vestnik of Nosov Magnitogorsk State Technical University, 2013, 3, 62-66 (in Russian)]

[2] Копцева Н.В., Голубчик Э.М. , Ефимова Ю.Ю. и др. Особенности формирования комплекса физико-механических свойств в высокопрочных инварных сплавах. Сталь, 2014, 4, 97 99 [Koptseva N.V., Golubchik E.M., Efimova Iu.Iu. Features of formation of the complex physicomechanical properties of high-strength invar alloys. Stal, 2014, 4, $97-99$ (in Russian)]

[3] Чукин М.В., Голубчик Э.М., Гун Г.С. и др. Исследование физико-механических свойств и структуры высокопрочных многофункциональных сплавов инварного класса нового поколения. Вестник Магнитогорского государственного технического университета им. Г.И. Носова, 2014, 1, 43-47 [Chukin M.V., Golubchik E.M., Gum G.S. et al. Study of physico-mechanical properties and structure of high-strength multifunctional alloys invar new generation of luxury. Vestnik of Nosov Magnitogorsk State Technical University, 2014, 1, $43-47$ (in Russian)]

[4] Чукин М.В., Копцева Н.В., Голубчик Э.М., Чукин Д.М., Медведева Е.М. Исследование режимов термической обработки при производстве высокопрочных инварных сплавов нового поколения. Металлург, 2014, 4, 97-101 [Chukin M.V., Koptseva N.V.,Golubchik E.M., Chukin D.M., Medvedeva E.M. The study of heat treatment in the production of high-strength invar alloys of new generation. Metallurg, 2014, 4, 97-101 (in Russian)] 